\title{
Straight Vegetable Oil as a Diesel Fuel?
}

Concerns about U.S. reliance on imported petroleum and fluctuating fuel prices have led to growing interest in using biodiesel, an alternative fuel made from vegetable oils. However, there is also interest in the direct use of vegetable oils as straight or raw vegetable oil (SVO or $\mathrm{RVO}$ ), or of waste oils from cooking and other processes. These options are appealing because SVO and RVO can be obtained from U.S. agricultural or industrial sources without intermediate processing. However, SVO is not the same as biodiesel, and is generally not considered to be an acceptable vehicle fuel for large-scale or long-term use.

While straight vegetable oil or mixtures of SVO and diesel fuel have been used by some over the years, research has shown that SVO has technical issues that pose barriers to widespread acceptance.

\section{Performance of SVO}

The published engineering literature strongly indicates that the use of SVO will lead to reduced engine life. This reduced engine life is caused by the build up of carbon deposits inside the engine, as well as negative impacts of SVO on the engine lubricant. Both carbon deposits and excessive buildup of SVO in the lubricant are caused by the very high boiling point and viscosity of SVO relative to the required boiling range for diesel fuel. The carbon buildup doesn't necessarily happen quickly, but instead over a longer period. These conclusions are consistent across a significant body of technical information in multiple articles and reports.

A recent technical paper ${ }^{1}$ reviews published data on the use of SVO in engines. Quoting from this paper:

Compared to No. 2 diesel fuel, all of the vegetable oils are much more viscous, are much more reactive to oxygen, and have higher cloud point and pour point temperatures.

Diesel engines with vegetable oils offer acceptable engine performance and emissions for short-term operation. Long-term operation results in operational and durability problems.

Some investigators have explored modifying the vehicle to preheat the SVO prior to injection into the engine. Others

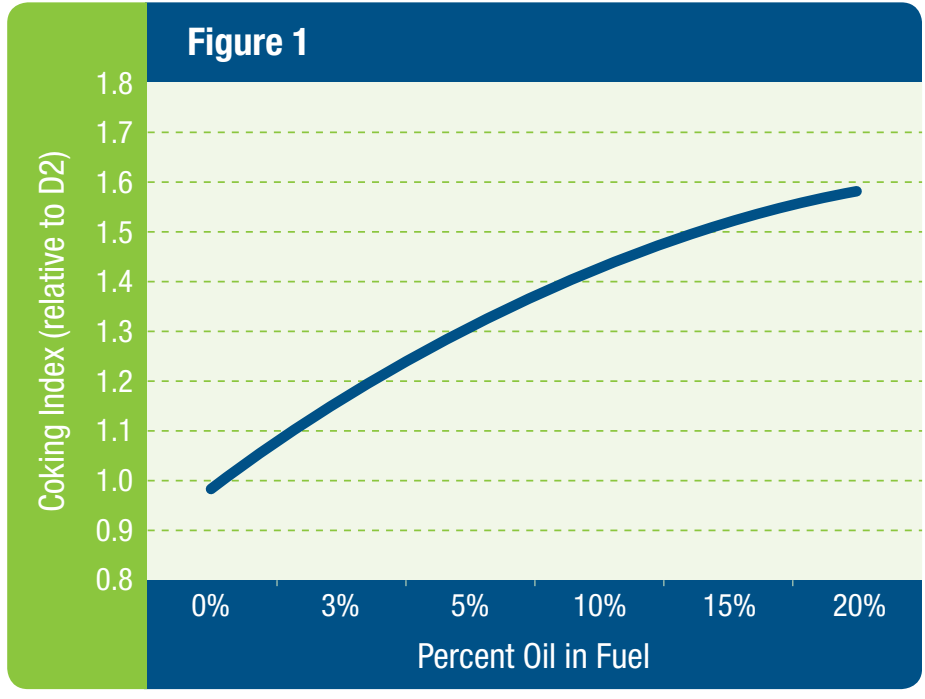

have examined blends of vegetable oil with conventional diesel. These techniques may mitigate the problems to some degree, but do not eliminate them entirely. Studies show that carbon build up continues over time, resulting in higher engine maintenance costs and/or shorter engine life. Figure 1 shows how the tendency to form carbon deposits increases with blending of a vegetable oil into a diesel fuel. ${ }^{2}$

Another issue that is particularly critical for use of neat (100\%) SVO is fuel viscosity. As Figure 2 (next page) indicates, the viscosity of SVO is much higher than that of diesel fuel at normal operating temperatures. ${ }^{3}$ This can cause premature wear of fuel pumps and injectors, and also can dramatically alter the structure of the fuel spray coming out of the injectors to increase droplet size, decrease spray angle, and increase spray penetration. All of these changes

'Babu, A.K.; Devaradjane, G. "Vegetable Oils And Their Derivatives As Fuels For CI Engines: An Overview." SAE Technical Paper No. 2003-01-0767.

${ }^{2}$ Jones, Samuel T.; Peterson, Charles L.; Thompson, Joseph C. Biological and Agricultural Engineering Department, University of Idaho, Moscow, Idaho, USA. "Used Vegetable Oil Fuel Blend Comparisons Using Injector Coking in a DI Diesel Engine." Presented at 2001 ASAE Annual International Meeting, Sacramento, California, USA, July 30-August 1, 2001. ASAE Paper No. 01-6051.

${ }^{3}$ Bruwer, J.J., et al. "Use of Sunflower Seed Oil in Diesel Engined Tractors." Proceedings of the IV International Symposium on Alcohol Fuels Technology; October 5, 1980, Guaruja, SP, Brazil. 
to the fuel spray will tend to increase wetting of engine internal surfaces with the fuel leading to increased tendency to form carbon deposits and dilute the lubricant.

The long-term effect of using SVO in modern diesel engines that are equipped with catalytic converters or filter traps is also a matter of concern. In general, these systems were not originally designed with SVO in mind, and can be seriously damaged or poisoned by out-of-spec or contaminated fuel.

\section{Biodiesel: Fuel made from SVO}

Biodiesel is an alternative fuel that can be made from SVO in a chemical process called transesterification that involves reaction with methanol using caustic soda (sodium hydroxide) as catalyst. Biodiesel has substantially different properties than SVO, and results in better engine performance. In particular, biodiesel has a lower boiling point and viscosity than does SVO. Because of its improved qualities, vehicle and engine manufacturers are more willing to support use of biodiesel blends in their products, which will ease some of the barriers to introducing a new fuel.

The quality of biodiesel is governed by specifications developed by the American Society for Testing and

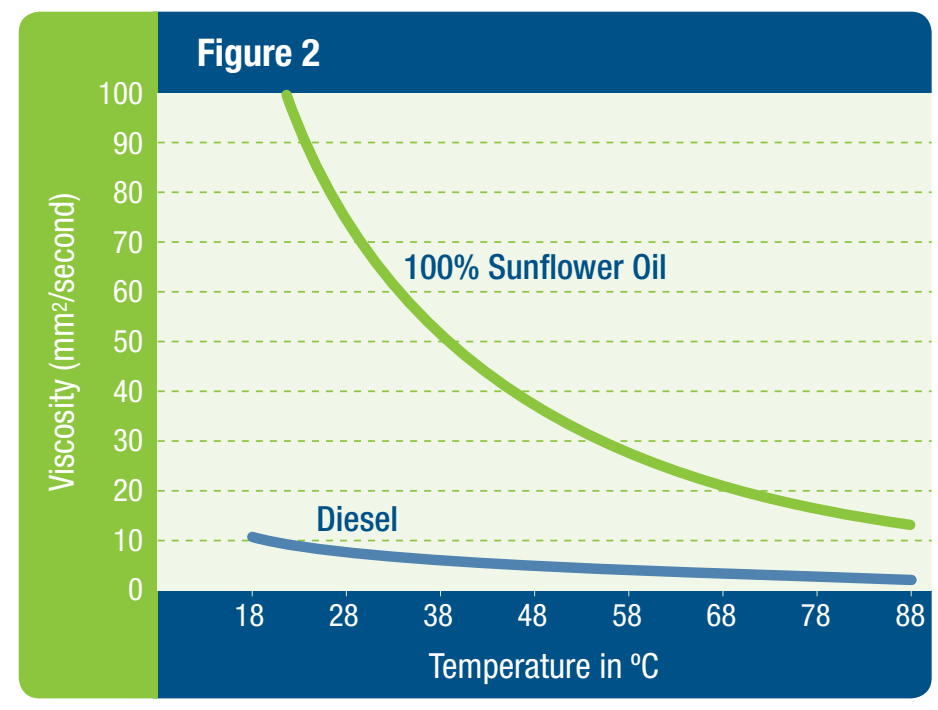

Materials (ASTM). The specifications are for pure biodiesel (B100), which can be used in blends up to a maximum of $20 \%$ by volume biodiesel. ASTM specification D675103a is intended to ensure the quality of biodiesel used in the United States, and any biodiesel used for blending should meet this specification. Biodiesel that meets ASTM D6751-03a is also legally registered as a fuel and fuel additive with the U.S. Environmental Protection Agency. For a complete list of ASTM biodiesel requirements, see the 2004 Biodiesel Handling and Use Guidelines at $w w w$. nrel.gov/docs/fy05osti/36182.pdf. In addition, the National Biodiesel Board is instituting a quality assurance program for biodiesel producers and marketers. To learn more about the BQ-9000 program, visit the National Biodiesel Board at www.biodiesel.org.

\section{Where can I get more information?}

- The Clean Cites activity has produced a fact sheet on biodiesel blends. It is available at www.eere.energy.gov/ cleancities/blends/pdfs/37136.pdf.

- The U.S. DOE's Alternative Fuels Data Center at www.eere.energy.gov/afdc is a vast collection of information on alternative fuels and alternative fuel vehicles.

- The U.S. Department of Energy's Office of Energy Efficiency and Renewable Energy website at www.eere.energy. gov/biomass contains information on biodiesel and ethanol production and policy.

- The National Biodiesel Board is the national trade association representing the biodiesel industry. Its website, www.biodiesel.org, serves as a clearinghouse of biodiesel related information.

- The National Renewable Energy Laboratory's Nonpetroleum Based Fuels website, located at www.nrel.gov/ vehiclesandfuels/npbf, provides links to a variety of biofuels documents.

- The Environmental Protection Agency's Biodiesel Emissions Analysis Program at www.epa.gov/otaq/models/biodsl.htm contains a biodiesel emissions database.
Sponsored by the U.S. Department of Energy

Energy Efficiency and Renewable Energy

FreedomCAR and Vehicle Technologies Program

For more information contact: EERE Information Center

1-877-EERE-INF (1-877-337-3463)

www.eere.energy.gov

A Strong Energy Portfolio for a Strong America

Energy efficiency and clean, renewable energy will mean a stronger economy, a cleaner environment, and greater energy independence for America. Working with a wide array of state, community, industry, and university partners, the U.S. Department of Energy's Office of Energy Efficiency and Renewable Energy invests in a diverse portfolio of energy technologies.

DOE/GO-102006-2315 • April 2006
Prepared by the National Renewable Energy Laboratory (NREL) NREL is a U.S. Department of Energy National Laboratory Operated by Midwest Research Institute $\bullet$ Battelle

Neither the United States government nor any agency thereof, nor any of their employees, makes any warranty, express or implied, or assumes any legal liability or responsibility for the accuracy, completeness, or usefulness of any information, apparatus, product, or process disclosed, or represents that its use would not infringe privately owned rights. Reference herein to any specific commercial product, process, or service by trade name, trademark, manufacturer, or otherwise does not necessarily constitute or imply its endorsement, recommendation, or favoring by the United States government or any agency thereof. The views and opinions of authors expressed herein do not necessarily state or reflect those of the United States government or any agency thereof.

Printed with a renewable-source ink on paper containing at least 50\% wastepaper, including $10 \%$ postconsumer waste. 